\title{
HOSPITAL PLANNING: REVISED THOUGHTS ON THE ORIGIN OF THE PAVILION PRINCIPLE IN ENGLAND
}

\author{
by
}

\begin{abstract}
ANTHONY KING
OF the many domestic reforms hastened by the Crimean War, the rethinking of hospital design was one which most concerned the mid-Victorian architect. The deplorable state of military hospitals revealed by the Report of the Commission appointed to inquire into the Regulations affecting the Sanitary Condition of the Army, the Organization of Military Hospitals and the Treatment of the Sick and Wounded, 1858, ${ }^{1}$ stimulated the discussion of civil hospital reform ${ }^{2}$ which was already active in the mid-1850s. The change which took place from the early to the late nineteenth century, from conditions 'where cross-infection was a constant menace' to those 'where hospitals [were] of positive benefit to a substantial number of patients's occurred largely in the years following this report; improved medical knowledge, nursing reforms, increased attention to sanitation, and better planning and administration, combined to ensure that Florence Nightingale's maxim-'The first requirement in a hospital is that it should do the sick no harm' - was far less relevant in 1890 than it had been fifty years before.

Prior to 1861 , there had been a considerable variety of different architectural designs for hospitals in this country, 'but in the 1870 s and 1880 s, the vast majority of new hospitals and rebuilt hospitals conformed to one basic plan-a series of separate pavilions placed parallel to one another'. ${ }^{5}$ The 'pavilion system', as conceived by its advocates, consisted preferably of single storey, or failing this, two-storey ward blocks, usually placed at right angles to a linking corridor which might either be straight or enclosing a large central square; the pavilions were widely separated, usually by lawns or gardens. In the wards, complete cross-ventilation was achieved by opposite rows of tall, narrow windows reaching from floor to ceiling. Natural ventilation, from doors, windows and fireplace was the rule. This uniformity of design among late Victorian hospitals, with its emphasis on spaciousness and natural ventilation, was the logical outcome of the general acceptance of the aerial conduction of disease, or, as it was known to contemporaries, the miasmic or pythogenic theory.

The popularity of the pavilion system, expensive in terms of site value, building costs, administration, and maintenance, lasted well into this century. Moreover, with the rapid expansion of hospital facilities between 1861 and $1891,{ }^{\circ}$ the twentieth

1 Parliamentary Reports and Papers, 1857-8, xviii (1).

2 B. Duncum, 'The Development of Hospital Design and Planning', in F. N. L. PoYNTER (ed), 'The Evolution of Hospitals in Britain', London, Pitman Medical Publishing Co., 1964, p. 214.

B. ABeL-SMTTH, 'The Hospitals', London, Heinemann, 1964, pp.1-2.

- Florence Nightingale, Notes on Hospitals, 3rd ed., London, 1863, p. iii, Quoted in ABelSMITH, op. cit., p. 1 .

ABel-Smith, op. cit., p. 154.

- Ibid., see also R. WARD, The Design and Equipment of Hospitals, London, Baillière, 1949, p. 7.
\end{abstract}




\section{Hospital Planning}

century was bequeathed a collection of medical buildings which, like its inheritance of schools and houses, has brought serious strain on the lives and activities of their inhabitants today.

The responsibility for this change, as well as for other aspects of hospital reform, is invariably attributed to Florence Nightingale, with little or no reference to others, both in biographies of her and in monographs on hospitals. 'Florence Nightingale's Notes on Hospitals revolutionized the whole theory of hospital management and hospital construction ... Instead of massive single buildings, she advocated the pavilion type of structure'; 7 the pavilion system 'was yet another field in which Miss Nightingale had a decisive influence' $;{ }^{8}$ 'In the 1860 s, the most authoritative voice defining what hospital wards should be like was Florence Nightingale's'. ${ }^{9}$ The best known biography of the Victorian heroine, by Cecil Woodham-Smith, conveys the impression that reforms in hospital design, together with the introduction of various changes, from a clean water supply to the provision of a chute for soiled linen, were not only attributable solely to her, but states that 'abyssmal ignorance of the first principles of hospital construction existed even among educated and liberal-minded people'. ${ }^{10}$ In the recent biography of Sir John Simon, hers is the only name associated with the pavilion system. ${ }^{11}$

Many of these assumptions probably come from the most detailed biography of Florence Nightingale by Sir Edward Cook ${ }^{12}$, where, though acknowledging his subject as 'a pioneer of advocating the pavilion system in this country', ${ }^{13}$ Cook goes on to say that Notes on Hospitals 'revolutionized many ideas, and gave a new direction to hospital construction'. The only dissenting opinion discovered by this writer is that in a recently-published volume on hospitals, which, while maintaining that Miss Nightingale's views on nursing organization were widely accepted, affirms that 'her recommendations on design and construction were often ignored' ${ }^{14}$ Insofar as her advocacy of the pavilion system was successful, the statement is also somewhat misleading.

While not attempting to minimize Florence Nightingale's part in helping to bring about the acknowledged change, this article aims to qualify these opinions in three important respects. It demonstrates that other interested parties, surgeons and architects, were actively engaged and were successful in bringing about changes in the state of English hospitals prior to Miss Nightingale's influence. It suggests too, that her Notes on Hospitals was, in all probability, strongly influenced by the writings of another hospital reformer, John Roberton, and that three articles, previously attributed to her, are in fact his. Lastly, it attempts to show that the editor of the most influential representative of the architectural press, George Godwin of The Builder, social reformer and promoter of the public health cause, was important in

' Courtney Dainton, The Story of England's Hospitals, London, Museum Press, 1961, p. 117.

8 ABEL-SMTtH, op. cit., p. 154.

- Nuffield Provinical Hospital Trust, Studies in the Function and Design of Hospitals, London, 1955 , p. 2.

10 C. Woodham-Smith, 'Florence Nightingale', London, Penguin, 1955, pp. 256-8.

11 R. LAMBERT, Sir John Simon, London, MacGibbon \& Kee, 1963, pp. 344-5, 478-83.

12 Sir E. T. COOK, The Life and Work of Florence Nightingale, 2 vols., London, Macmillan, 1913.

13 Ibid., vol. I, p. 340, pp. 416-7.

14 B. Duncum, op. cit., p. 216. 


\section{Anthony King}

focusing attention on hospital design among that profession most concerned with it. It is likely that his espousal of the cause of hospital reform, his support of the 'pavilion system' and his co-operation with its advocates, including Florence Nightingale, did much to determine hospital design from the late 1850 s.

The Builder had been founded in 1842 by J. A. Hansom, the inventor of the cab named after him. Two years later, Godwin took over the editorial chair which he was to keep until 1883. In the years following Edwin Chadwick's Report on the Sanitary Condition of the Labouring Population, and particularly in the 'fifties and 'sixties, Godwin conducted personal investigations into the London and provincial slums and used The Builder as a powerful vehicle for information and reform. Every aspect of 'the sanitary movement' came under his pen: inadequate drains and sewerage, polluted water supplies, the prevention of intra-mural burial, urban slaughter-houses, noxious trades, to mention only a few. Two topics were of paramount importance for him: the need for adequate ventilation in all public and private buildings, and the shortage of decent homes for the working-class population. So great indeed was his reputation in his own profession, that on his death in 1888, the President of the Royal Institute of British Architects, Alfred Waterhouse, said 'probably the cause of sanitary science owes more to him than to any other man' ${ }^{15}$ From the foundation of the National Association for the Promotion of Social Science, in 1857, to its demise in 1883, Godwin was a regular attender at its meetings and from 1859, a member of the Council. As President of the Health Section in 1871, he was the only architect, and the only journalist, of the twenty-seven occupants of that post, who included eleven doctors and six barristers, to be so honoured. His concern for public health was an important, though not the only interest in a long career. The sub-title of The Builder in 1868, so well reflecting his editorial campaigns as well as indicating a prospective circulation, illustrates the variety of his reforming activities: 'An Illustrated Weekly for the Architect, Engineer, Archaeologist, Constructor, SanitaryReformer and Art-Lover.'16

Hospitals, as any other form of building, received due, but not exceptional attention in the early years of The Builder. The importance of good ventilation, however, (which was, of course, the raison d'être of the pavilion system) had featured prominently in the columns since Godwin had taken over, stimulated particularly by the building of the Houses of Parliament and the controversy over the merits of various systems of mechanical ventilation. It was the discussion of a similar mechanical (as opposed to 'natural') system, introduced at Guy's Hospital in 1853, which first revealed Godwin's scepticism of the efficiency of 'scientific ventilation', in this case, the so-called 'descending system', about which he was careful to add his own reservations. ${ }^{17}$

The principal controversy over ventilation in hospitals, and the fundamentally allied question of design and layout, for Godwin in The Builder, for Florence Nightingale, and for the medical world at large, was prompted by the beginning of the Victoria Military Hospital at Netley, Southampton, in May 1856. This hospital, built

\footnotetext{
16 Royal Instrtute of British ARChitects, Proceedings, Vol. 4, new series, February 9, 1888.

16 For Godwin's interests in housing reform and art, see A. King's articles in Architectural Review, December 1964; Victorian Studies, Vol. VIII, No. 2, 1964.

17 The Builder, 19 February 1853, p. 116.
} 


\section{Hospital Planning}

on the old system, of a corridor from which the wards opened off, was immediately condemned' by Florence Nightingale, in a private letter, who urged that the French pavilion system should be used.18 $\mathrm{A}$ descriptive account of Netley appeared in The Builder of 23 August 1856,19 but apart from a reservation about the amount of space per patient in the wards, there were no other criticisms. The following month, however, Godwin devoted a complete two-page leader to his views on hospitals. And at this point, these views were very much influenced by those of a medical contemporary whose reforming activities seem to have been neglected.

John Roberton (1797-1876), a Scottish-born surgeon, educated in Glasgow and Edinburgh, had intended starting life as a ship's surgeon. Sailing to the West Indies, his ship had been wrecked on the Lancashire coast, and Roberton, after a short period of practising in Warrington, moved to the Manchester Lying-In Hospital where, in 1827, he was appointed surgeon. Here, he became known for his work on midwifery and diseases of women and children, publishing important papers on these subjects. Later, he turned his attention to hospital construction and the provision of convalescent homes, embodying his ideas in a number of pamphlets. ${ }^{20} \mathrm{His}$ wide range of interests, shown by the many papers read to the Manchester Statistical Society, confirms a contemporary's opinion of him as 'an eminent and most laborious surgeon, a deep thinker, a voracious reader, and pre-eminently the friend of the poor and suffering.' 21

Roberton's views on hospital construction were given to the Manchester Statistical Society on 20 March 1856, in a paper entitled 'On the Defects, with reference to the Plan of Construction and Ventilation, of most of our Hospitals for the reception of the Sick and Wounded'.22 The paper begins with a fairly lengthy account of the importance of ventilation and is very critical of the means adopted for it in English hospitals. The aim of ventilation was to prevent a hospital atmosphere . . . which

${ }^{18}$ W. J. Bishop and SUE GoLDIE, A Bio-Bibliography of Florence Nightingale, London, Dawsons, 1962 , p. 91.

10 The Builder, 23 August, 1856, pp. 457-8.

${ }^{20}$ Dictionary of Natural Biography.

21 'Answers to Objections against Vaccination', 1839.

'Report on the Amount and Causes of Death in Manchester', 1845;

'On the Proper Regulations of Labourers engaged in the Construction and Working of Railways', 1845;

'Voluntaryism (in education) an amiable Delusion', 1853;

'Suggestions for the Improvement of Municipal Government in Populous Manufacturing Towns', 1854;

'On the National Schools of Ireland', 1855;

'On the Defects, with reference to the Plan of Construction and Ventilation of most of our Hospitals for the reception of the Sick and Wounded', 1856;

'On certain Legalized Forms of Temptation as Causes of Crime', 1857;

(A criticism of the laws on bastardy, seduction and licensing);

'Additional Suggestions with a view to the Improvement of Hospitals', 1858;

'The Insalubrity of the Deep Cornish Mines . . . and the Physical Degeneracy and Early Deaths of the Mining Population', 1859;

'A Model Warehouse', 1860;

'On the Need of Additional as well as Improved Hospital Accommodation for Surgical Patients in Manufacturing and Mining Districts', 1860;

'On the Laws of Nature's Ventilation and their application in the Construction of Dwellings, Schools and Public Buildings', 1862;

'The Duty of England to provide a Gratuitous, Compulsory Education for the Children of her Poorer Classes', 1865.

22 Manchester Statistical Society, Transactions, 1855-6, pp. 133-148. 


\section{Anthony King}

arises from the wards communicating with one another by passages and stairs'.23 The plan of most of our hospitals was bad and in none was it such as to prevent the 'hospital atmosphere'. On the continent, this object had been attained in several instances. Roberton had visited St. John's Hospital, Brussels, the new Lariboisière Hospital in Paris, the Beaujon Hospital in Paris, all of which he thought welldesigned; but that at Bordeaux, he preferred as 'at once ingenious and perfectly successful'. ${ }^{24}$ Here, each ward had thirty-eight beds, nurses' offices were at one end, and lavatory and closets at the opposite extreme end. From the windows, on both sides of the ward, giving cross-ventilation, could be seen 'a beautiful garden planted with vines and roses'; each ward had only one door; each patient had not less than 2,000 cubic feet of space; each pair of pavilions had a garden between. Roberton spoke highly of the ventilation apertures above the ward windows, covered with perforated zinc plates which, at all times, allowed a free circulation of outside air. He had 'little faith in scientific ventilation . . . whether the downward mode, the upward mode, or the circuitous mode'. ${ }^{25}$ All the windows should be tall, from floor to ceiling. This ventilating system he had seen at the Middlesex Hospital in May 1855 , and had been very impressed with it. As for heating, apart from the open fireplace or stove, artificial modes of heating were injurious; patients were surrounded by an unnaturally dry, hot atmosphere which increased their discomfort. Ceilings and walls were to be highly varnished to prevent imbibition of effluvia by the plaster. The site was to be on an elevation, if possible, to the windward of the city, to be large enough to include gardens, and the soil was to be naturally dry. Accident rooms should exist in each of the larger municipal wards of a city, as was the case in Paris. These suggestions, extended in Roberton's second paper two years later, coincide with the most essential points which Florence Nightingale was to embody in her Notes on Hospitals in 1859.

Two months later, the paper was published as a pamphlet, with a plan of Bordeaux Hospital, 'and forwarded to the medical officers of the London Hospitals; the heads of the Army medical department; to the officers of the General Board of Health'26 and, in all probability, to certain editors of the local and national press. On 20 September 1856, a month after The Builder had published its description of Netley, taking Roberton's pamphlet as his authority and text, Godwin devoted the whole of a two-page leader to the subject of hospitals and a criticism of Netley, publishing also the plan of the Bordeaux Hospital. Quoting extensively from Roberton, Godwin stressed that 'one of the most important facts, if not the most important, is a plentiful supply of fresh air'. With illustrations from The Builder's past record, Godwin confirmed that 'we have long fought for fresh air-fresh air everywhere'. Mr. Roberton's views ought to be universally adopted. 'Some of our military hospitals are disgraceful to the scientific character of our country'. Godwin, a reputable architect in his own right, had 'not been in one without finding some error in its design? Quoting from Gwilt's Cyclopaedia of Architecture, he affirmed that the principle of insulation of each apartment had been laid down in France seventy years previously.Godwin's

23 Ibid., p. 138.

24 Ibid.

25 Ibid., p. 143.

${ }^{26}$ Manchester Statistical Society, Transactions, 1857-8, p. 23 footnote. 


\section{Hospital Planning}

own familiarity with continental hospital plans came from an acquaintance with continental professional literature. His knowledge of the new hospital at Malines, constructed in July 1854, with its lawns between the pavilions twice as wide as the height of the wards, with the small ante-room between wards and latrines, 'a much more important matter than some in England seem to think', had come from the Journal Belge de l'Architecture'. Godwin was equally familiar with recent French designs. As for Netley, 'some very serious mistakes had been made', particularly in the placing of the latrines between sick-wards. If this were not remedied, 'more disease will be generated there than cured.'27

The appearance of these comments in The Builder soon prompted a correspondence. 'Several correspondents' wrote confirming Godwin's views, and Dr. Roberton himself suggested that a Government Commission of Inquiry should be set up to investigate the hospitals. ${ }^{28}$ 'C.E.' thought 'the country much indebted' to Godwin 'for noticing the Victoria Military Hospital, as also for giving Mr. Roberton's and your own remarks'. The letter was particularly critical over the placing of the wards, storey over storey, with latrines between. Godwin was confirmed in his views by 'numerous adhesions' to the idea 'that the French plan was the correct plan'; i.e. detached wards, windows on both sides opening from the ceilings; latrines divided from the wards and under a separate roof; corridors between the wards, open at the top. ${ }^{29}$

Netley, and the promotion of the pavilion system, had brought the whole question of hospital ventilation to the fore. Between October 1856 and January 1857, comments and correspondence on the matter in The Builder covered the whole field from the diffusion of gases to the defence of particular ventilation schemes. S. E. Rosser, the contractor for the system installed at Guy's in 1853, was obliged to defend his reputation against growing opinion in favour of 'natural ventilation' ${ }^{30}$ His opponent in the correspondence columns was Dr. George Corfe. ${ }^{31}$ Corfe thought Rosser's views 'largely theoretical' and not to be confused with his own, which were founded on twenty-five years' experience at the Middlesex Hospital. His advocacy of the pavilion system was backed by impressive views which no doubt carried much weight with architectural sanitary reforms and others of the environmentalist school. It was clear that 'morbific matter' was 'thrown off from the bodies of sufferers and passes into the air with the noxious gases which emanate from the skin of patients'. These gases then traversed floor after floor. The noxious vapours 'were always specifically heavier than the upper warm strata of air of the ward, so that they are confined to the lower portion of the room, where, like oil floating on water, with pure air above, they stagnate, until copious streams of cold and lighter air glide along the floor from doors and windows, and thus the aerial poison is driven to the chimney flues and to the ceilings'. In the fever wards of certain metropolitan hospitals, when a variety of cases were admitted, it was sometimes found that fever did not spread. This was not only due to the better ventilation here, but also 'to the fact that the worst forms of

27 The Builder, 20 September, 1856, pp. 509-10.

28 Ibid., 28 September, 1856, p. 526.

20 Ibid., 4 October, 1856, p. 544.

so Ibid., 25 October, 1856, p. 581.

-1 Surgeon at the Middlesex Hospital and author of The Physiognomy of Diseases, 1849, and $A$ Popular Treatise on the Kidney, 1839. 


\section{Anthony King}

typhus are counterpoised, in their baneful influence, by the pungent emanations of other diseases, as acute rheumatism, etc., or the foetid exhalations of a sloughing back or a gangrenous lung'. The fact was, that 'the poison of contagion is wrapped up in the bosom of other noxious exhalations of a gaseous nature', and only a ceaseless flow of external air could carry off the fetor from 'ulcers, wounds, burns and vitiated excretions' ${ }^{32}$ This, according to Corfe, had been achieved at the Middlesex, where the ventilation system had been changed three times in the previous fifty years. Now, not only was direct ventilation obtained through openings at the top of the wards, but all closets had double doors which prevented foul air diffusing outside. ${ }^{33}$

By June 1857, the Netley designs were being roundly criticized in press and parliament. In the Commons, 'Mr. Stafford had affirmed that the building was being constructed "in defiance of all those sanitary precautions which our bitter experience in the Crimea ought to have taught us" '. The British Medical Journal, which Godwin quoted, had repeated his own assertion that the hospital would kill more patients than it would ever cure. It was 'a conspicuous engineering blunder'. Again, Godwin laid down the correct principles of construction as displayed by the pavilion system. At Netley, 'all the wards will communicate with one common corridor which will serve as a pipe to conduct the contaminated atmosphere of one ward to the comparatively pure air of its neighbour. ${ }^{34}$

That the agitation, of which this was only a part, had some effect, was proved by the Army Medical Board giving their approval to the plans of the new military hospital at Aldershot. Here, blocks three storeys in height, but with wards communicating with each other 'only by external staircases, preventing the circulation of impure air from one floor to the other', indicated a basic pavilion plan. According to Godwin, the designs 'were evidently founded on the plan, suggestions and reasonings' given in the pages of The Builder. The principle adopted was 'unquestionably the right one.,35

Of perhaps more importance was the projected building of Blackburn Infirmary which had become possible as the result of a public subscription started in 1856. A letter from J. Lang, formerly House Surgeon at University College Hospital, and then at the Manchester Royal Infirmary, was published in the Preston Guardian on 19 September 1857. One month before the best of the seventy-three plans submitted in competition was selected, the letter urged the adjudication committee to adopt a plan based on the system recently carried out in France. Lang, who had inspected all the hospitals of London and Paris, recommended the isolation of each ward; entrances from the open air; no blank walls in the wards; opposite floor-to-ceiling windows and wards for thirty patients, heated by open fires or stoves. Some of the recently-built hospitals in the country have been very badly planned. ${ }^{36}$ The following week, the subject was taken up in the editorial columns. Roberton's pamphlet, sent by the author to the editor, was again quoted at length. According to the Preston Guardian, both The Lancet and The Builder had done much to point out the evils of bad construction: the failings of Netley were well known. 'The subject of hospital architecture had been

32 The Builder, 17 January, 1857, pp. 36-8.

23 Ibid., 15 November, 1856, p. 624.

34 Ibid., 13 June, 1857, p. 340.

25 Ibid., 11 July, 1857, p. 396.

36 Preston Guardian, 19 September, 1857, p. 6. 


\section{Hospital Planning}

freely and fully discussed in The Builder and among its subscribers' and the obvious plan to be recommended for Blackburn was 'the Continental model.'37

Blackburn Infirmary, the first civil hospital in England to be designed on the pavilion principle, ${ }^{38}$ was begun in January 1858 , the foundation stone being formally laid on Whit Monday of that year. It was a notable event, with poems written for the occasion, processions of children and friendly societies, crowds flocking in from all south-east Lancashire, a balloon ascent in the afternoon and a ball in the evening. The reason for these festivities arose not only from the consciousness of the success of the principle of self-help in this prosperous working-class town; a glance at the long account in the Preston Guardian indicates that the citizens of Blackburn proudly believed that they were making medical history in commissioning what was to be the best and most up-to-date hospital in the country. The arrangement was one of separate and distinct blocks of buildings, two storeys high, placed at intervals of twenty feet on opposite sides of a principal corridor. The blocks contained on each floor, a single ward of eight beds, with windows on both walls, so arranged as to separate the beds. Permanent ventilation openings over the windows ensured 'a constant but imperceptible flow of fresh air'. Closets were at the ends of the wards and separated from them by double doors. In the Preston Guardian's enthusiastic report, the Netley Hospital was 'a splendid monument of folly and an example to be avoided', built 'on a dismal swamp, skirting the Southampton river'. But Blackburn Infirmary 'supplies a nearly exact model for all parts of the kingdom'. Mr. James Turnbull, the Manchester architect, had 'availed himself of the labours of $\mathrm{Mr}$. Roberton and Mr. Godwin, who have devoted themselves long and patiently to the exposition of the true theory of hospital architecture ... The country has many specimens of what a hospital should not be; in a few months, this country will possess a specimen of what such an institution should be . . . England owes a debt to Lancashire ... It will perhaps be a long time before the views of men like Mr. Roberton are fully appreciated, although benevolent persons are beginning to comprehend the first principles of hospital construction'. It was 'a somewhat remarkable fact that no hospital or infirmary in England has been constructed on scientific principles. Architects appear to have misconceived or been totally indifferent to the design of these institutions'. The competition 'was the first instance in which the new views propounded by Mr. Roberton, and enforced by his disciples, were embodied by British architects in their plans. Henceforth ... the principles laid down in his pamphlet will rule the judgements in all future competitions of hospital architecture.' 39

The enthusiasm was unfortunately somewhat premature. The completion of the building was delayed as a result of the Lancashire cotton famine, the outcome of the American Civil War. Its unique place as the first 'pavilion type' hospital to be built in England was lost to the Herbert Military Hospital in Woolwich.40

This interest in hospitals, as well as The Builder's support of the environmentalist sanitary cause, obviously recommended it and its editor to Florence Nightingale. It is difficult to determine the exact date of contact between them, but one is tempted

s7 Ibid., 26 September, 1857, p. 2.

88 K. D. Young, On the Evolution of Hospital Design, London, 1910, p. 40.

20 Preston Guardian, 28 May, 1858, Supplement.

10 K. D. Young, op. cit., p. 40. 


\section{Anthony King}

to make Godwin the 'Unknown Correspondent' to whom Florence Nightingale wrote on 3 September 1857. In this letter she expressed her deep interest in the fate of Netley Hospital; if her correspondent could stay longer, she would be glad to see him regarding the matter, though her opinions were only practical while his were scientific; she was enclosing a copy of the evidence recently given by her before a Commission, with a paper where it touched the point of Hospital construction; she would be glad if he would look it over and return it, keeping it confidential until the Blue Book appeared.11

On the following Saturday, The Builder, prompted by the news of the Indian Mutiny, devoted a dramatically-worded leader to requesting (in unusually large type) 'The Immediate Organization of a Sanitary Commission to Proceed to India with our Army'. Godwin not only quoted evidence from the official reports on the Crimean War, but referred to the fact that 'another competent authority has estimated that one quarter of our army engaged in India will fall by fever, cholera, dysentery and other complaints'. The appointment of 'a distinct and sufficiently powerful body of sanitary officers, and also of workmen to carry out their instructions, to attend the army in India' was called for. ${ }^{42}$ It is not inconceivable that some collaboration between the two reformers had taken place here.

Whilst the subject of hospitals was being discussed by Roberton and Godwin, Florence Nightingale was preparing her Report, including her recommendations on hospitals, for the Royal Commission on Barracks and Hospitals, in the latter part of 1856 and the earlier part of $1857^{\prime} .^{43}$ The Commission began taking evidence in May 1857, and Miss Nightingale's answers to the written questions submitted to her were inserted at the date of $20 \mathrm{July}$. The Report was finally published early in 1858 .

In March of that year, Roberton, again at the Manchester Statistical Society, had delivered a second paper entitled 'Additional Suggestions, with a view to the Improvement of Hospitals, for the Sick and Wounded'.44 Exception, it seemed, had been taken to the remarks on 'scientific ventilation' in his previous paper, in a letter to The Builder (No. 759, p. 485) 'The editor of that valuable journal, however, I am happy to observe, understands the true science of ventilation, and is rendering, from time to time, important service to humanity by his articles on the subject' ${ }^{45}$ The main fault with 'scientific ventilation', according to Roberton, was its unreliability. His views on the superiority of natural ventilation, promoted by the pavilion system, had been confirmed by a tour of hospitals in Holland, Belgium and Germany, undertaken in the summer of 1857. He had visited hospitals in Ghent, Antwerp, Liège, Cologne, Hanover, Hamburg, Berlin, Dresden, Leipzig, Frankfurt and Bonn. ${ }^{46}$ The aspects which particularly concerned him, and to which this paper gives attention, are the placing of the latrines, drainage and water supply, lighting, floor and wall surfaces, and facilities for the recreation of patients, " a matter more cared for on the Continent

41 The original of this letter is in the Columbia University Presbyterian Hospital School of Nursing. Transcript of contents from the Welkome collection.

42 The Builder, 5 September, 1857, p. 501.

13 E. T. CoOK, op. cit., I, p. 342.

44 Manchester Statistical Society, Transactions, 1857-8, pp. 23-47.

45 Ibid., p. 24.

10 Compare C. Woodham-Smith, op. cit., p. 256, for statement on Florence Nightingale's unique experience of overseas hospitals. 


\section{Hospital Planning}

than in this country. ${ }^{97}$ Roberton advocated more reading rooms, libraries, and gardens and terraces where patients could walk. He had been particularly impressed with the fine gardens at Lariboisière. The recent report of the Barrack and Hospital Commission had disclosed certain appalling facts; 'but let us hope that our civil hospitals too would be the subject of a commission of inquiry'. This would certainly disclose 'a mass of remediable evils such as must speedily result in the pulling down and reconstruction, on a better model, of a number of buildings'. ${ }^{48}$

Roberton was gratified that in the report 'a number of the suggestions of my former Paper re-appear, more or less, in the evidence of the most eminent witnesses', particularly with regard to the support of the pavilion system and the prevention of 'an hospital atmosphere'. Other suggestions he approved of favoured natural ventilation, lighting in the wards, and the injurious effect of artificial heating. Roberton quoted Florence Nightingale's evidence here, in detail, adding, in a footnote: 'Miss Nightingale's evidence ... will be read with profound attention. It well deserves to be printed by itself, and put into general circulation for the benefit of professional men, whether attached to the army or in civil life, but especially for the use of governors of hospitals and even for the instruction of architects'.49 Roberton thought that the memorials presented to Lord Panmure, Secretary of State for War, by the medical staff at the Middlesex Hospital, condemning Netley, as well as the debate in the Commons, had stimulated the Commissioners in the execution of their work.

As with Roberton's first paper, this soon found itself the subject of a Builder leader. In the issue of 19 June 1858, headed 'Construction of Hospitals. Ventilation. Blackburn Infirmary', Godwin set out further criticisms of the present unreformed practice. Present-day physicians still presided over hospitals 'erected on plans illcalculated to aid in the restoration of health'. At the time of the building of Netley, The Builder had criticized the plan, 'but we were pooh-poohed by some and abused by others'. Subsequently however, reports had proved his assertion that 'more diseases were generated there than cured'. 'Many of our provincial and some of our London hospitals are most unhealthy'. Again, most of Roberton's recent paper is reproduced, including his extracts of Florence Nightingale's evidence to the Royal Commission. Above all, Godwin was behind Roberton in his insistence on 'nature's ventilation for the displacement of the foetid effluvia ever being admitted from the bodies of the sick and wounded, and the substitution instead of air, not drawn from cellars, corridors and passages, but admitted from the store of the unpolluted heavens'. At Blackburn, the pavilion system had been adopted and was 'admittedly founded on Dr. Roberton's papers and the observations in our own pages.' ${ }^{50}$

By now, The Builder's promotion of Roberton had earned a tit-for-tat relationship for Godwin. On 26 June the surgeon wrote to thank the editor 'for his able leader on hospital ventilation'. He was 'truly happy to perceive that this important subject, the right construction of hospitals ... has so vigorous an exponent and avocate as The Builder.' ${ }^{51}$

This continued sympathy for the cause of hospital reform again recommended

"1 Manchester Statistical Society, Transactions, 1857-8, p. 33.

48 Ibid., p. 38.

so The Builder, 19 June, 1858, p. 417.

s1 Ibid., 26 June, 1858, p. 438. 


\section{Anthony King}

The Builder to Florence Nightingale when she began her renewed campaign against Netley in July 1858. The recently published report of the Barrack and Hospital Commission had come out quite clearly on the side of the 'pavilionists': 'In the construction of new hospitals, we recommend the plan of separate pavilions, with lateral windows on opposite sides, and natural ventilation'. Other recommendations, advised by Florence Nightingale and previously suggested in Roberton's papers, reinforced by The Builder, referred to the use of Parian cement or other impervious material, for walls and ceilings instead of bare brick and plaster; the need for efficient sewerage which did not pass under the buildings; the need for the removal of all cesspools in the immediate vicinity of the hospital, and the isolation of the closet and sink facilities from the main building by a ventilated lobby. ${ }^{52}$ The Report had endorsed her opinions on Netley which she had unsuccessfully tried to press on Lord Panmure two years previously. Now, however, 'she embarked on a strenuous press campaign in the hope of winning support for her cause'. ${ }^{53}$ One of a series of unsigned letters to various papers was sent to The Builder and formed a large part of the leader for 24 July 1858 . After tracing the history of the Netley difficulties, the leader once more laid down the basic principles of good hospital construction. Not one of them had been adopted at Netley. 'Not fewer than five hundred sick were placed under one roof'; the whole building was erected 'on the muddy banks of a tidal estuary'. Though the pavilion principle 'had made great advances in the public estimation since we advocated it', and had been recommended by the Royal Commission and adopted at Aldershot, Woolwich and Blackburn, there were still members of the Committee reporting on the Netley Hospital whose reports 'mainly served to show the great want of acquaintance with the subject'. Though this press campaign, and the activities of other antagonists, failed to change the basic designs of Netley, certain modifications were undertaken. It was the defeat on this matter which, according to Cook, 'suggested to Miss Nightingale the importance of instructing public opinion on the question of Hospital Construction. She accordingly contributed two papers on the subject to the Social Science Congress at Liverpool in October 1858. ${ }^{\text {s4 }}$

The content of these papers, however, was already well known to readers of The Builder, and disciples of Roberton, at least six and certainly one month before they were delivered at Liverpool. On 28 August, Godwin announced his intention 'of devoting two or three papers to a discussion on hospitals'. There was 'hardly a hospital in the country which fully embodied all the essential sanitary principles'. This leader, entitled 'Sites and Construction of Hospitals', was followed by two others, equally lengthy and detailed, on 11 September and 25 September: 'The Construction of Hospitals: The Ground Plan' and 'Hospital Construction: Wards'. The articles concluded by summarizing twenty-one main points covering sites, position, air and water supply and all internal and external details.

These three articles have previously been attributed to Florence Nightingale ${ }^{55}$ on

52 Report of the Commissioners appointed to Inquire into the Regulations affecting the Sanitary Conditions of the Army, the Organization of Military Hospitals and the Treatment of the Sick and Wounded, 1858. 1857-8, xviii, (1).

ss Bisfop and GoLDIE, op. cit., p. 91.

s E. T. COOK, op. cit., I, p. 383.

ss Ibid., II, Bibliography, Appendix A. (11). Also, Bishop and Goldie, op. cit., p. 91. 


\section{Hospital Planning}

an assumption made from the Preface to Notes on Hospitals, 1859: 'In order to make the information on hospital construction as complete as possible, three papers from The Builder, of 28 August, 11 September and 25 September, have also been reprinted, by the kind permission of Mr. George Godwin, who has paid much attention to the subject. They present similar views on the architectural arrangement of hospitals. ${ }^{36}$

Godwin was not adverse to acknowledging the origin of ideas introduced into his leaders: Roberton's name had been used freely previously, and following the publication of the Barrack and Hospital Report, the more well-known name of Florence Nightingale was frequently quoted in The Builder to lend further authority to opinions. If the articles had been written by her it is likely that they would have been acknowledged. More definite proof, however, is given in 1860. In discussing hospital plans in The Builder, Dr. Coombe, a medical officer of the Royal Artillery, writes, 'The latest, and as far as I know, the best and completest details of these principles (of construction) are to be found in the various papers by Mr. Roberton of Manchester, which have appeared in The Builder, especially three in August and September of 1858 , and in the papers by Miss Nightingale which were read to the Social Science Association at Liverpool.'57

It is clear from this that these three important articles, bound together with Miss Nightingale's Social Science Congress papers (these in all probability influenced by Roberton's writings: see below), and her evidence to the Royal Commission, and forming the first and second editions of Notes on Hospitals, were written by Roberton and edited, and perhaps added to, by Godwin.

The two articles presented to the Liverpool Congress identified four radical defects in construction: the agglomeration of a large number of sick under one roof (with the ensuing recommendation of the pavilion system), and the deficiency of space, ventilation and light. There is nothing of great importance in these two papers which had not previously been publicized in greater detail by Roberton, either in the reprinted papers of the Manchester Statistical Society or in the columns of The Builder. Moreover, Miss Nightingale was willing to give these other reformers credit for their activities. Apart from the reference to Godwin in the Preface of the first editions of Notes on Hospitals, in the original Congress papers she had said: 'This country is much indebted to Mr. Roberton of Manchester, to the medical staff of the Middlesex Hospital and to the Army Sanitary Commission for their advocacy of the pavilion system of hospital construction, in opposition to the corridor system, as also for their enlightened labours in the cause of good hospital construction generally'. ${ }^{58}$ At the end of her paper, perhaps taking the hint from Roberton's pamphlet (see above, p.369), she appealed 'to those who are wiser and have more practical power than I, for the remedies-to architects, to hospital committees, to civil and royal engineers, to medical officers, to officers of health, to all men of science and benevolence.'59

Roberton's last paper on hospitals was contributed to the Manchester Statistical

b6 FloRence Nightingale: Notes on Hospitals, London, 1859, preface.

${ }^{57}$ The Builder, September 1860, p. 606.

s8 FloRenCE Nightingale: Notes on Hospitals, being two papers read before the National Association for the Promotion of Social Science at Liverpool, in October 1858, with evidence given to the Royal Commissioners on the State of the Army in 1857, London, 1859, p. 15.

so Ibid., p. 21. 


\section{Anthony King}

Society in November 1860. Entitled 'On the Need for Additional as well as Improved Hospital Accommodation for Surgical Patients in Manufacturing and Mining Districts, but especially in Manchester', it presents a well-informed and convincing case for the expansion of hospital facilities. The need arose from the prevalence of casualties in connection with the industrial pursuits of the population. Evidence existed in abundance from the reports of Factory Inspectors, Inspectors of Coal Mines, annual printed lists of accidents in metallic mines and of patients admitted to Manchester Royal Infirmary. Blackburn and Ashton-under-Lyme were building their own Infirmaries; but so far, Preston, Warrington, Bury, Bolton and Oldham were all without adequate facilities. ${ }^{60}$

Subsequent connections between Florence Nightingale and Godwin are beyond the scope of this paper, which is confined to the reform of hospital planning. Suffice it to say that in the following year, 1859, she assisted Godwin in a somewhat testy and argumentative correspondence with Dr. E. H. Greenhow on the subject of contagion, and shortly after, lent her support to The Builder in the campaign to move St. Thomas's Hospital to a rural site. ${ }^{61}$ Critical reading of other items in these years can detect certain other of her ideas incorporated in general questions on sanitary reform. That no definite proof of this can be given confirms Miss Nightingale's own opinion of Godwin's journal: The Builder was 'a discreet little paper which always puts me in', she wrote to Sir Harry Verney. ${ }^{62}$ In her Notes on Nursing, she referred to it as 'that excellent paper, The Builder.' ${ }^{\prime} 3$

Godwin's interest and influence in hospital architecture was firmly established by 1858. From then on the subject received considerable attention in his paper. His opinions were repeated in the reprinting of much of the reformist content of his editorials between 1854 and 1859 in his illustrated book, Town Swamps and Social Bridges, published early in 1859. Architects submitting designs in competition for the projected Infirmary at Ashton-under-Lyme were referred by the responsible committee to The Builder for professional advice; when their report appeared, the opinions of Godwin, Roberton and Florence Nightingale were quoted frequently. ${ }^{64}$ The Ashton, Blackburn and Woolwich Hospitals were watched closely and extensive comment made on their progress. It was 'quite clear that a large amount of hospital building should be at once undertaken throughout the country'. ${ }^{65}$ When the General Report of the Commission for Improving the Sanitary Condition of Barracks and Hospitals was published in April 1861, it confirmed the views advanced by The Builder, ${ }^{66}$ justifying Godwin's statement that 'we have the satisfaction of knowing that our pages, in conjunction with the endeavours of Dr. Roberton and the admirable Miss Nightingale, have made known throughout the country the right principles of hospital construction, and have prepared both the medical and architectural profession to make right use of the accumulated information on the subject, now sent out by the

00 Manchester Statistical Society, Transactions, 1860-1.

61 B.M. Add. Ms. 45770, ff. 72, 77, 88; 43398. f. 117.

22 BisHOP and GOLDIE, op. cit., p. 92.

as FlORENCE Nightingale, Notes on Nursing, London, 1860, p. 21, footnote.

ot The Builder, 18 June, 1859 , p. 402-3.

os Ibid., 2 July, 1859, p. 433.

os General Report of the Commission for Improving the Sanitary Condition of Barracks and Hospitals, P.P. 1861, xvi. 1. 


\section{Hospital Planning}

Commissioners appointed by the Secretary of State for War. Journalists ... may look for no higher reward than to see their opinions put forward authoritatively by those in power, and brought into practice'. ${ }^{67}$ According to a surgeon at the Suffolk General Hospital, the main authorities on hospital construction were 'the two Government Reports on the construction of hospitals and barracks; the admirable series of articles in The Builder newspaper; the Notes on Hospitals by Miss Nightingale and the Report issued by the governors of the Newcastle Infirmary. ${ }^{68}$

Godwin's claim that 'the right principles of hospital construction had been made known throughout the country' rests on proof of an extensive circulation. Partial substantiation of this is provided by the statements of the Preston Guardian. Though circulation figures are not available, The Builder, some years later, was referred to as 'one of the finest properties in the categories of the weekly press. Its circulation is large . . . It enjoys among engineers, architects, builders and the members of other kindred professions and trades a reputation of the highest kind' ${ }^{69}$ If it can be assumed that contributors to the paper in 1856 and 1858 , when the principles were first propounded, were also readers, then clearly, these principles must have reached some of the most eminent architects of the day: George Gilbert Scott, Benjamin Ferrey, G. E. Street, T. L. Donaldson, William Burgess, Charles Barry, Robert Kerr, Sydney Smirke, J. W. Papworth, A. Pannizi, W. Hosking, E. W. Godwin and H. A. Darbishire, to mention only the most well known.

This article has attempted to show the influence, not only of a lesser-known surgeon, John Roberton, in promoting hospital reform, but also, of a newlyestablished trade and professional journal in bringing about one particular instance of change in social and architectural history. For the historiographer, it illustrates the tendency for subsequent generations to encourage the development of the heroworshipping history of Carlyle's England. And in the words of the 1858 President of the British Association, Professor Owen, it attempts to draw attention to the work of hitherto neglected professions in the great nineteenth century movement of public health reform: 'the professors of new arts, which are only partially created-the art of the sanitary architect and the art of the sanitary engineer', exponents of the new discipline of 'sanitary science."'70

${ }^{67}$ The Builder, 8 June, 1861, p. 390.

os Ibid., 21 September, 1861, p. 647.

60 J. GRANT, History of the Newspaper Press, London, 1872, p. 122.

${ }^{70}$ The Builder, 2 October, 1858, p. 653. 